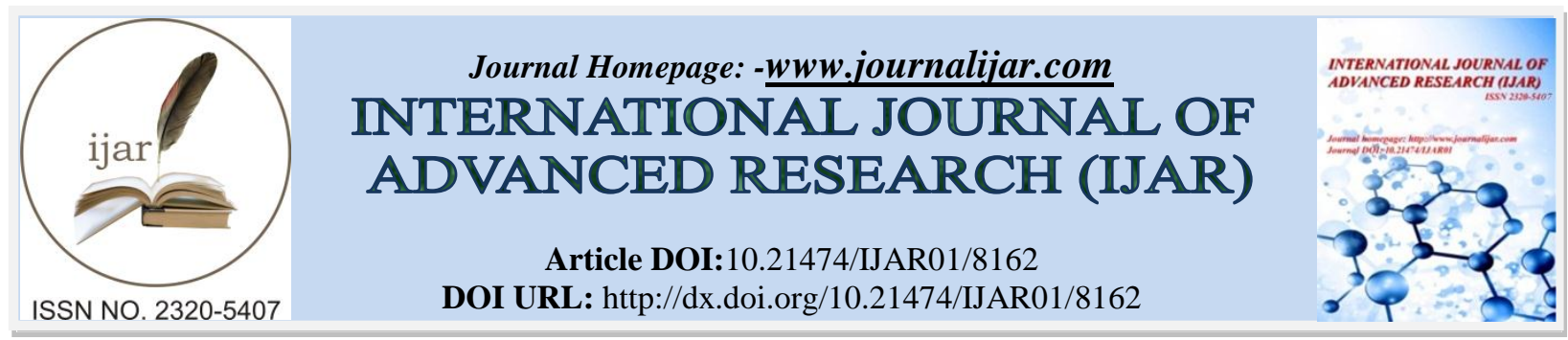

RESEARCH ARTICLE

\title{
MARKETING THE PROJECT DEVELOPED LANDED HOUSES BASED ON THE AGREEMENT TO SEL
}

Subekti, SH. M. Hum ${ }^{1}$, Prof. Moch. Isnaeni, SH. MS ${ }^{2}$ and Dr. Hj. Endang Prasetyawati, SH. M. Hum ${ }^{3}$.

1. Doctoral candidate of the Faculty of Law Universitas 17 Agustus 1945 Surabaya; Lecturer in Law and the Head of a Postgraduate Program (Masters of Law) at the Faculty of Law Universitas Dr.Soetomo, Surabaya, Indonesia.

2. Emeritus Professor in Law at UniversitasAirlangga, Surabaya-Indonesia.

3. Associate Professor in Law and the Head of the Postgraduate (Ph.D) Program in Law at the Faculty of Law Universitas 17 Agustus 1945 Surabaya.

\section{Manuscript Info}

\section{Manuscript History}

Received: 04 October 2018

Final Accepted: 06 November 2018

Published: December 2018

Keywords:

Sale, Agreement to Sell, Landed Houses, Law Protection.
Abstract

The existence of the agreement to sell or the what so called "the Commitment of Sale and Purchase Agreement" in marketing the Project Developed Landed Houses in Indonesia arises as a consequence of pending fulfilment of the existing conditions required to form a contract of sale of any landed houses. The using of the agreement to sell has appeared to halt the completion of the contract of sale (sales) of landed houses or properties. There seems to be a two steps contractual relationships, and this has seemed to cause problems of uncertainty to the party sitting in the position as consumers or the buyers of the project developed landed houses in Indonesia. No legal protection infavour of the buyers or the consumers of the landed properties. The research has found that there has been two steps before a contract of sale of the landed houses is finaly formed. The nature of the first step the legal relationship is a preliminary one. It is an in personam contract; the contract is termed as a anagrement to sell. It has a nature of conditional sale, as recognised by the Article 1458 of the Indonesian Civil Code. In a conditional contract, the condition is suspensive, performance of the obligation is delayed, or suspended, until the condition is purified. Meanwhile the nature of the second step of the contractual relation is in rem. This is, in the law, be reconed as a real contract. This second type of contract has been coined as the contract of sale, and it is also enforceable in the buying and selling of the landed houses. Adat law upholding this institution as a real contract (in rem). The seller (the Developer) of Landed Houses may transfer the property (i.e. the ownership) in the goods as part of the contract of sale of the landed houses.The law of contract has always subject to all public policy to protect consumersinvolved in the buying and selling of the Project Developed Landed House. The law of sale of the landed house is subject to the Indonesian National Land Law Number 5 of 1960. 


\section{Introduction:-}

The rapid development of the property business sector, especially the construction of the landed houses has emerged a new phenomenon regarding the practicing of the landed house sale and purchase and their land rights by basing on agreement to sale, or in Indonesia has been coined as "the Commitment of Sale and Purchase Agreement". This phenomenon happens because the documents which become the basis of the rights transfer has not been done by the developers. According to the definition that is regulated in Law Number 5 of 1960 reffered asthe Basic Agrarian Law Act, it is considered that one of the way to transf the land rights is through a mechanism of selling and purchasing. The sale and purchase must be done by creating an authentic deed made before the official certifier of title deeds that is known as the Sale and Purchase Deed.

Regarding the requirements that have not been fulfilled to carry out the Sale and Purchase Deed between the developers and the consumers, then to anticipate this situation, the landed house selling and purchasing can be done first and the developers and the consumers agree to make a Commitment of Sale and Purchase Agreement for the landed houses.

The Commitment of Sale and Purchase Agreement is made from the conception of the Indonesian Civil Code which is an agreement between the parties regarding the rights and the obligations made by basing on the Article 1320 jo. The Article 1338 of the Indonesian Civil Code, so that it is expected to provide legal certainty and legal protection for the parties who make it. However, the undone of the landed house sale and purchase through the making of the Sale and Purchase Deed before the Official Certifier of Title Deeds) which is required by the law can harm the consumers. If the consumers have paid the sale price, the freehold title of the house will not be granted or transfered from the developers since the unfulfillment of the requirements which has been asked by the law.

Problems that often occur in fulfilling the need on the housing are the consumers aspects, especially when they are in a disadvantaged position. Many cases occur the estate business, for instance cases involving incompatibility in handovering the house that is mostly out of the due date, the certificates of freehold title that are not completed, architectural drawings, house designing and building engineering specifications, quality of building that is not in accordance with the agreement, and other facilities such as water installation, electrical intallation, and environmental infrastructure facilities (public and social facilities).

There are two problems to uncover in this research. Firstly, what is the legal position of the consumers as the landed house owner after a real submission or levering done by the developer? Secondly, what is the legal protection for the consumers in a landed house sale and purchase agreement?

This research is normative legal research. The problem approach used in this study is philosophical approach (filosophie approach), statutory approach (statute approach), conceptual approach (conceptual approach). Sources of legal material use primary legal materials, namely legislation and secondary legal materials, namely archives, official government data, legal books, journals, magazines that are published relating to the problems of study. Analysis of legal material is carried out by first identifying the collected legal material, then describing it, systematizing it by basing it on the scientific theory of law and concepts of law, principles or principles of law.

\section{Consumer Legal Position after Levering of the Landed House:-}

The legal relationship that occurs between the developer and the consumer in the landed house transaction with the Commitment of Sale and Purchase Agreement is the result of a contract that is based on the freedom of contract principle, which is one of the main principles in civil law, especially in a contract law. The principle of freedom of contract is contained in Article 1338 paragraph (1) of the Indonesian Civil Code. This provision confirms "All Agreements that are made legally apply as laws for those who make them".

The principle of freedom of contract becomes the basis for the emergence of landed house buying and selling with the Commitment of Sale and Purchase Agreement which is an immoral contract. The parties which is involved in the landed house purchase and sale contract with the Commitment of Sale and Purchase Agreement are the developers and the consumers or buyers.

The Commitment Sale and Purchase Agreement of the landed house is included in the agreement with tough conditions. This can be seen from the conditions where the documents on which the rights are transferred have not been resolved by the developer. The Commitment of Sale and Purchase Agreement of the landed house is a 
consensual agreement, meaning that the agreement was created when both parties reached an agreement on objects and prices even though at that time the goods had not been delivered and the price had not been fully paid (Article 1320 paragraph (1) jo Article 1458 Indonesian Civil Code).

The contract can only be created by the intent or will of the parties. This becomes a fundamental principle of binding contract law to be implemented as soon as they have reached an agreement. Thus, freedom of contract in the theory of classical contract law has two main ideas, namely contracts based on agreements and contractsas a product of free will.

According to the classical theoretical view of this contract, the parties who make this contract are equal, the parties also have the ability to determine fair bargains between them. This view is in line with that the contract is a product made by the parties (with freedom to determine) and also in accordance with the spirit of free market and free competition. The main concept of contract law ideas in the nineteenth century is the linking of broad will autonomy with the idea of unlimited contracting freedom.

The point of view is that the contract resulting from the free will of the parties and the contract is created at the meeting of the will of the parties, then the principle of consensualism is born. Consensus is the core and the basis of the concept of modern contract law. This principle basically states the idea that what is essential in a contract is the will of the parties

There are three stages in the process of making the Commitment of Sale and Purchase Agreement of the Landed House. Those are as follows: 1. Pre-contractual stage, namely the existence of offer and acceptance; 2 . The contractual stage, that is, the conformity of the statement of intention between the parties; 3 . Post-contractual stage, namely the implementation of the agreement.

The pre-contractual stage is the stage where the parties conduct negotiations to determine the contents of the agreement which they will later agree on. This stage, the developer has made a site offer through brochures or advertisements byincluding promises, such as providing facilities. Consumers are affected by reading the advertisement and finally buying the offered house. If the consumer is interested in one house, then before the sale and purchase agreement which by law must be compiled using a notariil deed in the form of a deed of sale, the parties make the Commitment of Sale and Purchase Agreement.

According to the classical contract theory or conventional theory, the bond between the parties means that the promises of the developer are considered to not materialize at the pre-contractual stage so that they are not binding at all. In contrast to conventional theory, in modern theory, promises at the pre-contractual stage are considered binding. So basically the concept that the agreement only binds at the contractual stage has shifted. The meaning is that the agreement has bound the parties both at the pre-contractual, contractual and post-contractual stages.

According to the modern contract theory, "Agreement is a legal relationship because of two legal actions which are one-sided, namely offering and receiving based on agreement between two or more people that are related to cause legal consequences". ${ }^{1}$ The definition does not only review the contract at the contractual stage solely but also considers the actions before and after them. The previous action includes the offer and acceptance stages, while the subsequent actions are the implementation of the agreement. The meaning of the agreement has bound the parties both at the pre-contractual, contractual and post-contractual stages.

The marketing system for landed houses has two agreements, namely the the Commitment of Sale and Purchase Agreement and the Sale and Purchase Agreement. The Commitment of Sale and Purchase Agreement is an obligatory agreement included in the treaty law stipulated in Book III of the Indonesian Civil Code while a sale and purchase agreement is included in the scope of national Land Law which is subject to Law Number 5 of 1960.

The Sale and Purchase Agreement is an agreement made by the parties when the object does not yet exist which is an agreement to carry out the sale and purchase agreement before the Land Deed Maker Officer (Public Notary) if the building has been completed and is certified and is habitable. The agreement on the sale of a house and house

\footnotetext{
${ }^{1}$ Mariam Darus Badrulzaman, Kompilasi Hukum Perikatan, Citra Aditya Bakti, Bandung, 2001, h.86.
} 
sale and purchase is included in the agreement with tough conditions. This can be seen from the conditions where the documents on which the rights are transferred have not been resolved by the developer.

According to the provisions stipulated in Law Number 5 of 1960 concerning Basic Agrarian Laws, it is stipulated that one way to transfer land rights is through a mechanism of buying and selling. The sale and purchase must be done by making an authentic deed made before the Official Certifier of Title Deeds known as the Sale and Purchase Deed.

Based on the principle of freedom of contract, the form of the Contract of Agreement for the Sale of Landed Houses is a standard contract. The contract has been prepared by the developer. The contract contents of the House Buy and Sell Agreement are made without being discussed with the consumer while the consumer is only asked to accept or reject the contents, if it is accepted then it is signed if not then leave. Therefore, standard or standard contracts are often said to be take it or leave it contract. Based on the description above, it can be understood that the essence of the Agreement on the binding of the sale and purchase of a house is a contract that has been standardized by the developer while the consumer is only asked to accept or reject the contents.

The obligation of the developer is to build a house in accordance with the conditions stated in the Sale Contract or what in Indonesia is called the Agreement to Buy and Sell. The obligation of consumers or buyers is to pay the price of the house site either in cash or installments until it is paid off to the developer. The relationship between the developer or developer and the consumer or buyer in the Agreement on the binding of the house sale and purchase is a contractual relationship. The general provisions in Book III of the Civil Code still apply in the contractual relationship.

Developers who have not been able to submit a land certificate on which there is a house building because there are several conditions that cannot be fulfilled by the developer, it is still the obligation of the developer to submit the site to the buyer. Consequently, when the handover is carried out, which is usually symbolized by the key handover and the handover report, as stated in Point V of the Minister of Manpower Regulation In the case of houses being objects of the Bond Sale and Purchase the building has been completed in accordance with the agreed period, and throughout the buyer has finished fulfilling the obligation to pay the price of land and building of the house along with other costs, the seller and the buyer agree to sign the minutes of the handover of the land and building of the house.

According to the Agrarian Law, what has been done by the developer has not yet been bought and sold, because the Basic Agrarian Law, the sale and purchase of land and buildings on it still uses Customary Law (Adat Law). The buyer only has the right to occupy and pay all the costs used for the facility. Based on Customary Law, the sale and purchase agreement is an agreement that is real in nature, meaning that the surrender of the promised goods is an absolute requirement that must be fulfilled for an agreement. In addition, it also adheres to the principle of light and cash, namely buying and selling in the form of surrendering rights for a long time and at that time the payment is also made by the buyer received by the seller.

Based on this case, the position of the buyer in the sale and purchase of the house with the Sale and Purchase Agreement is unclear, whether as the Recipient or the Attorney Holder from the developer or as a buyer or as a tenant or as what.

\section{Consumer Protection in Landed House in Sale Contract:-}

External legal protection is a legal protection provided by the authorities through regulations in the form of laws and regulations. ${ }^{2}$ The form of legal protection for consumers is contained in Law Number 8 of 1999 concerning Consumer Protection. In it there are articles that regulate safeguards for consumers who are violated by their rights. Therefore, for housing consumers whose rights are reduced due to unilateral actions from producers that harm them, both directly and indirectly will be protected by this law.

Article 18 paragraph (1) letter a is regulated regarding the prohibition on the inclusion of a standard clause in each document or agreement if it states the transfer of responsibility of the business actor. The Law on Consumer Protection also regulates the responsibility of business actors as stated in Article 19. According to Article 19,

\footnotetext{
${ }^{2}$ Moch. Isnaeni, Selintas Pintas HukumPerikatan (BagianUmum), Surabaya, Revka Petra Media, 2017 h. 41.
} 
"Business actors are responsible for providing compensation for damage, pollution and or loss of consumers due to consuming goods and or services produced or traded" Normatively there are provisions that regulate the responsibility of business actors, as an effort to protect consumers.

Legal protection for consumers can be achieved if fully implemented and supported by all parties involved, including producers or business actors themselves, consumers, the government, consumer institutions both private and government-owned. If all of the above devices optimize their respective roles, the safeguards expected by consumers will run optimally.

In addition to Law Number 8 of 1999, the manifestation of state protection for land-house consumers can be seen in Law Number 1 of 2011 concerning Housing and Settlement Areas. Article 42 reads as follows:

(1) Single houses, row houses, and/or flats which are still in the development process stage can be marketed through a system of preliminary buying and selling agreements in accordance with the provisions of the legislative regulations.(2)A preliminary sale and purchase agreement as referred to in paragraph (1) is carried out after fulfilling the certainty requirements for:a. Land ownership statusb. Promised thing; c. Ownership permits to establish the main building; d. Availability of infrastructure, facilities and public utilities; ande. Housing construction at least $20 \%$.

Article 134 of the Housing and Estate Law states that everyone is prohibited from carrying out housing construction, which does not build housing in accordance with the agreed criteria, specifications, requirements, infrastructure, facilities and public utilities. In addition there are also criminal sanctions stipulated in this Act, namely in Article 151 paragraph (1) and (2).

Decree of the Minister of Public Housing Number 09/KPTS/M/1995 concerning Guidelines for the Agreement on the Sale and Purchase governing the subject and object in the Agreement on Binding of Sale and Purchase of houses. In that decision, the developer is located as a seller, while consumers are domiciled as home buyers.

In addition to the above, there is also the obligation of the developer to submit the agreement object in the form of land and house at the time agreed. Due to late payment, the developer must pay a late fine. Provisions for fines in the Ministerial Decree are $2 / 1000$ (two-thousandths) of the total sale and purchase value.

Developers who neglect to give up the land and building houses according to the agreed time, the developer must pay a fine of $2 \%$ o (two-thousandths) of the total price of the house every day of delay. After the handover of the land and building, the seller is obliged to provide a period of maintenance or repairs within a period of 100 (one hundred) days from the date of signing of the Handover Minutes.

Legal protection for buyers is also found in Point 2 of Decree of the Minister of Public Housing. Developers who cannot surrender their land and buildings and their inherent rights on time even though the buyer has completed their obligations to pay the price of land and buildings or land and buildings that are submitted do not match the drawing plan and technical specifications of the building stipulated jointly and become an attachment in the binding of sale and purchase agreement to be canceled and the seller is obliged to return the money received plus a fine, interest and other fees in accordance with the provisions that apply according to the law.

Law Number 8 of 1999 concerning Consumer Protection, Law Number 1 of 2011 concerning Housing and Settlement Areas and Decree of the Minister of Public Housing Number 9 of 1995 concerning Guidelines for Binding of Sale and Purchase, through various regulations contained in it trying to resolve problems -problems, namely through regulating standard clauses, prohibitions for business actors, rights and obligations of business actors and consumers and so on, which have been potentially causing losses to consumers of site home buyers.

\section{Conclusion:-}

The legal position of the residents of the landed houose occupants after the real levering by the developer is not clear because the sale and purchase deed does not yet exist or has not been made because the conditions as specified in the sale and purchase agreement have not been fulfilled by the developer or developer. The site occupant's consumers only have a sale and purchase agreement, the sale and purchase agreement has not resulted in the transfer of ownership rights to a house from the seller to the buyer. This new stage is an agreement (consensual) and must be followed by a levering agreement, namely at the signing of the sale and purchase deed before the Land Deed Maker Officer. Consumers who live in the house have no sales and purchase certificates as a basis for issuing certificates. 
Consumer protection, in this is the landed house buyers, only gets external legal protection. External legal protection for consumers of site house buyers is contained in Law Number 8 of 1999 concerning Consumer Protection, Law Number 1 of 2011 concerning Housing and Settlement Areas and Minister of Public Housing Decree Number 9 of 1995 concerning Guidelines for the Agreement on the Sale and Purchase Agreement so that contracts that are made and binding on the parties will not harm the sense of justice, propriety, customs and law.

It is then suggested thatit is necessary to make a law that regulates explicitly the marketing system for the construction of site houses which, among other things, regulates the position of consumers after levering, but there is no deed of sale so that the position of consumers in buying and selling houses is clear. In addition, it also regulates the provisions that determine if a number of units have been sold, then a master certificate is broken down so that residents of the houses that have been submitted have proof of ownership of the land and the building.Standard contracts that have standard clauses in them before use must have an independent institution that checks whether the standard contract is balanced or not, appropriate or not so that the consumer gets legal protection.

\section{References:-}

1. Budiono, Herlien, Asas Keseimbangan bagi Hukum Perjanjian Indonesia, Hukum Perjanjian Berdasarkan Asas-Asas Wigati Indonesia, Bandung, Citra Aditya Bhakti, 2006;

2. ------, Perjanjian Baku (Standar) Perkembangannya di Indonesia,Bandung, Alumni, 2010;

3. Endang Prasetyawati, Metode Penelitian Hukum, Cetakan Pertama, Untag Press, Surabaya, 2010;

4. Hernoko, Agus Yudha, Hukum Perjanjian Asas Proposionalitas dalam Kontrak Komersial, Jakarta, Kencana Prenadamedia Group, 2014;

5. Isnaeni, Moch., Selintas Pintas Hukum Perikatan (Bagian Umum), Surabaya, Revka Petra Media, 2017;

6. Khairandy, Ridwan, Itikad Baik dalam Kebebasan Berkontrak, Jakarta: Program Pascasarjana, Fakultas Hukum Universitas Indonesia, 2003;

7. Leks \& Co, Tim Penulis, Hukum Real Estat Bagian 1 Hukum Pertanahan Perumahan dan Rumah Susun, Bandung, Citra Aditya Bakti, 2017;

8. Mertokusumo, Sudikno, Mengenal Hukum Suatu Pengantar, Yogyakarta, Liberty, 2001;

9. Miru, Ahmad dan Sutarman Yodo, Hukum Perlindungan Konsumen, Raja Grafindo, Jakarta, 2004;

10. Muhammad, Abdul Kadir, Hukum Perikatan, Bandung, Citra Aditya Bakti, 1990;

11. Patrick, Parwahid, Dasar-dasar Hukum Perikatan, Bandung, Mandar Maju, 1994;

12. Rajagukguk, Erman, dkk, Hukum Perlindungan Konsumen, Bandung, Mandar Maju, 2000;

13. Rudianto, Muchtar, Perjanjian Pengikatan Jual-Beli Sebagai Perjanjian Pendahuluan, Jakarta, Rajawali Press, 2010;

14. Reksomulyatno, Djoko, Perjanjian Pengikatan Jual-Beli Sebagai Perjanjian Innominaat, Jakarta, Bina Ilmu, 2010;

15. Santoso, Urip, Hukum Perumahan, Jakarta, Kencana Prenadamedia Group, 2014;

16. Siahaan, Hukum Konsumen Perlindungan Konsumen dan Tanggung Jawab Produk, Jakarta, Panta Rei, 2005

17. Sjahdeini, Sutan Remy, Kebebasan Berkontrak dan Perlindungan yang Seimbang bagi Para Pihak dalam Perjanjian Kredit Bank di Indonesia, Institut Bankir Indonesia, Jakarta, 1993;

18. Shofie, Yusuf, Perlindungan Konsumen dan Instrumen-Instrumen Hukumnya, Bandung, Citra Aditya Bakti, 2003;

19. Shidarta, Hukum Perlindungan Konsumen Indonesia,Grasindo, Jakarta2006;

20. Sutedi, Adrian, Tanggung Jawab Produk dalam Hukum Perlindungan Konsumen, Bogor, Ghalia Indonesia, 2008;

21. Antari Innaka, Sa'ida Rusdiana, Penerapan Asas Iktikad Baik Tahap Kontraktual pada Perjanjian Jual Beli Perumahan, Mimbar Hukum, Volume 24, Nomor 3, Oktober 2012;

22. Faizal Kurniawan dan Ayik Parameswary, Konstruksi Hukum Perlindungan Adhered Party dalam Kontrak Adhesi yang Digunakan dalam Transaksi Bisnis, Jurnal Perspektif, Vol. XIX, 2014;

23. Agus Yudha Hernoko, 'Keseimbangan Versus Keadilan Dalam Kontrak (Upaya Menata Struktur Hubungan Bisnis Dalam Perspektif Kontrak Yang Berkeadilan) http://repository.unair.ac.id/40106/1/gdlhub-gdl-grey2016-hernokoagu-40586-pg.05-16-h.pdf diunduh tanggal 10 Januari 2017;

24. Yuridika, Volume 32 Nomor 1, Januari-April 2017;

25. Kitab Undang-Undang Hukum Perdata (KUH Perdata);

26. Undang-Undang Nomor 1 Tahun 2011 Tentang Perumahan dan Kawasan Permukiman; 
27. Undang-Undang Nomor 8 Tahun 1999 tentang Perlindungan KonsumenUndang-Undang Nomor 5 Tahun 1960 Tentang Peraturan Dasar Pokok-Pokok Agraria;

28. Keputusan Menteri Negara Perumahan Rakyat Nomor 09/KPTS/M/1995 Tentang Pedoman Pengikatan Jual Beli;

29. Surat Edaran Otoritas Jasa Keuangan Nomor 13/SEOJK.07/2014 Tentang Perjanjian Baku. 